\title{
PATRIOTISM AND THE PACIFIC COAST
}

\author{
J. N. BOWMAN \\ University of California \\ I
}

The California state legislature in its late special session last December expressed itself regarding history and patriotism in a very amusing manner. In its Senate Concurrent Resolution No. 3 it regrets "that the Boston massacre was not the slaughter it was supposed to be," and other things of like nature. It makes patriotism rest on the facts and interpretation of history; and declares that any changes in facts or interpretations are disloyal and unpatriotic. History, the legislature feels, is taught and studied for no other purpose than patriotism; and even if it should be so studied and taught, it is patriotism that holds the whip of authority in deciding what is the true fact and the true interpretation. Though the resolution does not attempt to define patriotism, it does nevertheless give a negative definition, and thereby attempts to interfere with the freedom of thought, so dear to all Americans, and with the Lehrand Lernfreiheit, equally dear to all college and university men.

This resolution was incited by a local Sacramento paper and urged by the local G.A.R. The journal was no doubt sincere in its attack upon a harmless teachers' institute talk, on "Both Sides of American History"; but the relation between the teaching of history in the school system of the state and patriotism, as presented by the journal, is quite another question. The G.A.R. was no doubt equally sincere in wishing to preserve in the hearts of the present and rising generations a deep sentiment of country-love. But to rest this patriotism on the facts and interpretation of certain historical facts, raises at once the question, What is patriotism, and is it rooted in the dead past or in the living present? The legislature was quite as sincere no doubt in demanding harmonious co-operation among all the activities of the state. But when it attempts to define patriotism (negatively), it is surely forgetful of 
some of the past on which it wishes to base patriotism. It forgets the unpleasant attempt of a late Washington governor to direct university teaching; it fails to recall the Delbrück affair in the University of Berlin some years ago, and the Bernhard affair at the present time.

It is only a resolution; it is not a bill. It is one of the "hurrah, boys, hurrah" measures, as a legislator of long service explained it; a resolution whose passing is a passing into legislative oblivion.

\section{II}

Patriotism is a very difficult thing to define; yet it has been discussed from the days of Plato to the present. It seems to be a part of human affection, and may be said to be as old as attachment. It is earliest noted in the family and clan sentiment; its foundation is the blood-relationship; it has no relation to the land or country; for the home of the nomad or wandering tribe changes with water, pasture, and whim. The city of the burgher and the manor of the lord were localized, and the attachment to these has been called patriotism. The united manors, cities, and provinces-through royal conquest and compromise-resulted in the modern nations. And here it is that real patriotism in its modern sense begins. Some even contend that patriotism belongs alone to the nation or patria.

This blood-relation continues on through all the stages of development to the present. Today the "melting-pot" fuses the blood of most all of a nation's citizens; and where the "meltingpot" of blood fails, the "melting-pot" of interest and feeling completes the work. This blending process produces at least one product of great value: like-mindedness. If this is deep and widespread, a deep and widespread patriotism is the result.

To this blood-relation and to this interest-relation are added today two other things: country and history.

By country or patria is understood the land of the people's birth and rearing, the land that gives them home and livelihood. Their Jife is bound up in it and dependent upon it, so in struggling for life they are struggling for country.

By history, as an ingredient of patriotism, is meant the memories of the people in relation to their country-the known story of their 
struggles, victories, and sufferings in making themselves and their land what they are or what they would like them to be. History acts here as a guide-post; from it the blood and country interests can, in part, get their direction. History is what it is; it cannot be changed. The better patriotism accepts the past from the hands of those whose business it is to know the past. The lower patriotism accepts tradition as history and resists any change in it.

Patriotism is a democratic sentiment; it is as varied as the culture of the people and develops with them in their march upward. The lower patriotism, that of the lower class, is visual, concrete, martial, and often chauvinistic. The higher patriotism, that of the better classes, is more ethical, ideal, peaceful, and more cosmopoli$\tan$. Between these two ends is the long line of patriotism actuating the middle class. All are patriotic in the manner that most consistently expresses their sentiment toward their fellow-countrymen, their patria, and their past.

\section{III}

A past, a history, is a true part of patriotism. But how far back from the present does this history extend as a live and effective factor in patriotism? The answer of many nations may be gathered from their treatment of their national archives. The living part of the nation is often kept secret; while the dead part is open to the public. Speaking very generally, I8I 5 may be taken as a rough date dividing living from dead history in Europe. America brings the date almost to the present; and the president, at his discretion, may bring it to the very present moment. The treatment of state archives also gives an answer: papers from three to ten years old are still alive; papers over that age go to the archives as dead matter. Another answer may be found in Lorenz' Generationslehre: that a historical period covers only three generations - the passing grandparents, their mature and active children of the present, and the grandchildren. Bergson has given his answer in his idea of consciousness: the living present and its immediate memories. The national consciousness may be stated in almost the same terms.

Patriotism is of the present; it lives and moves, defends and 
conquers, raises ideals and struggles to realize them. In the field beyond this boundary patriotism can only hope; history alone can decide.

\section{IV}

\section{THE PACIFIC COAST AS A patria}

This term for America means the eleven states wholly or in part west of the Rockies. This contains about one-third of the area of the United States. It is about I,I 50 miles east and west and I,250 miles north and south.

Under the Indian the Coast remained in its natural state. The Spaniard entered it about four centuries ago and dotted it here and there with his missions, presidios, and ranches. The French held a part of it for nearly fifty years, but in all probability they scarcely set foot within its borders. The English were interested in it for nearly a century as a hunting-ground for the Hudson Bay Company. The Russian "passed in the night." The American entered it more than a century ago, and soon began to plant missions and ranches. Fifty years later began the great conquest that has not yet ended.

The fight for the home on the Coast has several phases. The fights with the Indian were neither long nor frequent. Conflicts between white people threatened several times, but actual engagements were short and not severe. The struggle with Nature has been constant and strenuous. She has claimed more energy and victims than Indian and white. And towns are not yet all planted; the roads and railroads are still in their early stages of building; the deserts have not yet fully surrendered; and there are places still awaiting the explorer.

Fights there were and are, but they are fights with Nature; and with such fights patriotism has little or nothing to do. Bones lie bleaching on the plains or buried in the mines; victories have been wrung from the soil and the mountains; cabins and trails still exist as ruined monuments of blasted hopes. These were parts of man's struggle for existence, livelihood, and fortune; only occasionally did any of these fights rise to the threshold of patriotism. The Coast has been bathed in sweat rather than blood.

The Coast has no Marathon, Lexington, or Sedan; in their 
place it has the Mother Lode, the Roosevelt Dam, and a rebuilt San Francisco. It has no Stratford, Weimar, or Concord; but it does have places where the "last spike" was driven. It has no Abbey, St. Denis, or Mt. Vernon; but it does have its plains, its mines, and its Donner Lake. It has no "Badenland" or "Dixie"; but it does have a "Watch Tacoma Grow."

\section{THE COAST AS A PEOPLE}

It was the Indian to whom the Coast was a real patria. $\mathrm{He}$ fought man and Nature and filled it with his associations. But we hardly associate patriotism with the red man. He has gone and has contributed nothing to the present patriotism.

The Spaniard had his centuries of struggle against Nature and whites. The missions and presidios, in ruins or in memory, recall to the living Spaniard the years of toil and suffering and ideals and disappointments. Problems once solved in the Southwest or on Puget Sound recall to him the greatness and the valor of his ancestors. But he, too, has gone; only a few remain on the Coast, either blending their blood and past and patriotism with the new and dominant people or retiring before the possessors.

To the memory of Drake has been erected the Cross in Golden Gate Park; in the Pacific Northwest are a few remains of the fur hunters and traders. These are of patriotic portent only to the few Englishmen still resident on the Coast. A new patriotism has here also been buried by a succeeding people.

The Dutch-Austrians scarcely more than touched the Coast. The Russian had slight interests on the Columbia and a settlement on the Californian coast; but the center was in Alaska and Siberia and not in these southern outposts. $\mathrm{He}$, too, has gone, and has contributed nothing to the existing patriotism. The French voyages to the Coast may have some slight patriotic meaning to a Frenchman; but of great patriotic possibilities were the factories and voyages, the songs and the jargon of the French-Canadian "coureurs de bois" and "voyageurs." They, too, have retreated with the retreating hunting-grounds; so that at present the people of Washington do not find the rivers recalling to them those "chansons" of the long ago. 
The Americans have a fair beginning. They have fairly well begun to make the Coast their patria. The Little Big Horn, the Lava Beds, and the Oregon Trail are of patriotic meaning, though it be to only a very few. They had their mission stations in the Northwest as the Spaniards had theirs in the Southwest. Astoria in a way recalls the grand ideals of a century ago. San Juan Island and the Columbia in the north, old Mexican foundations and other places in the south, recall to a gradually increasing number of Americans the old questions with England and Mexico. The "forty-niners" and the pioneers are becoming each year more deeply blended with the country. Camp and trail, forest and mountain are yearly attaching themselves to the memories of thousands of the Coast people. Memories of poets and writers are just beginning to find local habitation.

The American, in the slow process of patria-making, has accepted nothing from the Indian; in the north he has received something from the English and in the south also something from the Spaniard. But in each instance it is either an indirect or a second-hand patriotism. The American today is interested in the patria, the relics, and the past of these other people; but it is from the love for antiques rather than patriotism - they are not of the American past.

\section{V}

The American patriotism on the Coast today is still almost wholly imported. The Coast patriotism smacks of Lexington, Lake Erie, and San Juan Hill, of the fourth of July and of the Monroe Doctrine-all an inheritance from beyond the Rockies binding us to other parts of our larger people and our larger patria.

Professor Royce, a son of California, in an article some time ago, urged a Coast loyalty - a sectional patriotism to protect the American from the deadening influence of a national type. He is quite right in his ideal. The South has a patriotism as old as that of New England. Old Louisiana has a type that persists through the numerous descendants of French and Spanish possessors. Aside from these, Kentucky alone has a patriotism that merits the name.

The Coast has had but little to bind it together into a deep, conscious unity. No shot has been fired in danger or in war that 
has been heard around its borders. Abundant Nature has prevented the unifying famine. Freedom has not been threatened. Art and literature are in the early stages of their unifying influence. Trade and industry do unify-but no one can accuse them of being patriotic.

Patriotism has to grow on the Coast as it has grown elsewhere. The blood-bond must be closely drawn. The Coast American is from everywhere and the blood-blending is going on apace. The two generations of Americans have done well. They have added some of the Spanish, French, and English blood. But the great influx from the East and from Europe is faster than the blending can take place; and furthermore, the line is drawn at the Negro and the Oriental. To these limiting and retarding factors must be added the still greater retarding force of economic interest in the minds of the Coast people and the Coast immigrants. The patria-bond progresses but slowly; economic interests again interfere. There is scarcely a thing or ideal on the Coast as yet for which one can stake his life except the dollar. It is true that we are doing now what England, France, New England, and the South did either before or at the inception of their patriotism. The conquest of the land is a necessary step-but a step that must be so recognized and evaluated. The history-bond progresses still more slowly. The things that made possible a South, a New England, a Louisiana, and a Kentucky are impossible for the creation of a Coast. We had possibilities, perhaps, in the Chinese, Japanese, and Hindoo questions; the greatest possibility, however, is the frontage on the Pacific and the new world-life beginning on its shores. As yet our past is hardly available or adaptable to the cause of patriotism. The past is diverse and not centered in any common sentiment.

The lower patriotism finds here practically nothing; chauvinism must either import or create out of the blue. By nature this patriotism is interested in the static and in that which moves no more rapidly than itself and in the things as they were "supposed to be." A general, native Coast lower patriotism does not exist. The middle-class patriotism is somewhat more fortunate. It recognizes the Spanish, French, and English inheritance; it sees the world changing; it is interested in the present and the future; and 
is also willing to modify the imported patriotism. It sees the national patriotism as well as a possible Coast phase thereof. The higher-class patriotism is creative and leads the middle-class patriotism. It is sufficiently far removed from the East and the East's chauvinism to make a better evaluation of both the East and the Coast. It is demanding the entrance of "the West" into the histories and the textbooks; it sees the national errors and is striving to correct them. It leads in the initiative, referendum, and recall; in woman's suffrage and in juvenile courts; in insurgency and in the certification of high-school teachers. In coming west this patriotism left its chauvinism in the old home. The Coast is becoming the new center of the national life as the Middle West became the center after the War of 1812 . This higher, better, and enlightened patriotism is a refining influence in the whole nation; in the future it may become (yet one must devoutly hope not) as old and staid and chauvinistic as the patriotism of the East or the lower patriotism of the Coast.

The cosmopolitan tendency in national sentiment has its effect on the Coast as elsewhere. Labor and socialism here are uniting with the labor and socialism throughout the world under the slogan: "Proletarians of all countries, unite!" Art, learning, and science know no national boundaries. Ancestry and travel overlap the national lines. The Postal Union, the Red Cross Society, and the International Congresses are all making for a greater unity.

In conclusion, then: Patriotism is a natural, growing attachment of a people for their land; this attachment is felt by all the people, high and low. As yet there is no provincial patriotism on the Coast; the present patriotism is an importation; chauvinism finds here nothing at all. There is, however, the beginning of a high and a refined patriotism. This higher and better patriotism will eventually, it is hoped, permeate the middle and lower strata of patriotism until the great possibilities of the Coast produce a sectional sentiment that loves its own province, people, and past as deeply and dearly as it loves the great country as a whole. 